\title{
O neuroembriologicznych badaniach Wilhelma Hisa Starszego (183 I-1904) prowadzonych z perspektywy mechanistycznej
}

\author{
On the Neuroembriological Studies \\ of Wilhelm His Sr. ( 83 I-I 904) Conducted \\ from a Mechanistic Perspective
}

The article presents Wilhelm His Sr.'s (1831-1904) methodological path of research in the field of neurophysiological foundations, explained through specific mechanical causes. In this research context, the scholar searched for the so-called fixed cause-and-effect principle, which refers to the targeted development of the nervous system. His's pioneering research mainly focused on the structural genesis of the nervous system and the growth and development of embryonic neural cells.

Keywords: Wilhelm His, mechanics, vitalism, causality, neuroembryology Słowa kluczowe: Wilhelm His, mechanicyzm, witalizm, przyczynowość, neuroembriologia

\section{Wprowadzenie}

Pod koniec XVIII i na początku XIX w. najważniejszym zagadnieniem w biologii była organizacja życia. Problem podejmowano już w poprzednich okresach, jednak rozwój nauk biologicznych, np. morfologii, anatomii, fizjologii i ewolucjonizmu, spowodował jego kontynuację w odmiennych aspektach. Nie chodziło wprost o poznanie natury życia, o formułowanie jeszcze jednej jego definicji. Teraz badania biologów, koncentrowały się na wyjaśnieniu zasadniczych funkcji indywiduum żywego i ustaleniu praw nim rządzących. Stanowiska biologów co do sposobu wyjaśniania tych kwestii zróżnicowane były generalnie na dwie grupy: neomechanistyczne i neowitalistyczne'1. Do pierwszej grupy należał 
Wilhelm His Starszy (1831-1904) niemiecki embriolog, anatom i histolog. Wynalazł urządzenie zwane mikrotomem. Był uczonym, który wniósł ogromny wkład do nauki na obszarze anatomii ludzkiego mózgu oraz jego fizjologii. Pracował m.in. nad opisem nerwów czaszkowych w rozwoju mózgu oraz jego komory. Badał i klasyfikował substancje stymulujące ukierunkowany rozwój centralnego układu nerwowego. Jednakże najważniejszym jego obszarem zainteresowań była anatomia histologiczna oraz anatomia topograficzna. Szczegółowe badania, które prowadził na tym polu, dotyczyły głównie embrionalnego rozwoju poszczególnych organizmów m.in. zarodków ryb kostnoszkieletowych. Uczony skupiał także swoją uwagę na anatomicznych aspektach embriologii patologicznej oraz ewolucji układu nerwowego, rozpatrywanego w różnych aspektach badawczych².

Celem niniejszego opracowania jest opis, analiza oraz ocena podstawowego dorobku badawczego Hisa, ześrodkowanego głównie wokół koncepcji neomechanistycznej, adekwatnej - jego zdaniem - do wyjaśniania embriologicznych podstaw rozwojowych w toku rozwoju organicznego.

\section{O zajmowanym stanowisku, relacjach badawczych i wybranych publikacjach Wilhelma Hisa}

His żył w okresie, w którym na wielu uczonych studiujących medycynę w Lipsku duży wpływ wywarły badania Rudolfa Hermanna Lotzego. Warto zaznaczyć, że sam Lotze zasadę mechanizmu poznania świata rozumiał jako „nakaz” śledzenia przyczynowej metody wyjaśniającej, która opierała się na uznaniu monizmu naturalistycznego jako fundamentalnego stanowiska ontologicznego. Znaczny wpływ na kształtowanie się kierunku badań Hisa miał także Ernst Heinrich Weber, który przed nim kierował katedrą na Uniwersytecie Medycznym w Lipsku. Jednakże fundamentalną rolę w kształtowaniu się poglądów Hisa miała filozofia Immanuela Kanta. Przyrodnicy tego okresu często przejmowali od filozofa z Królewca pewne zależności poznawcze i „stosowali” je w odkrywaniu świata przyrody.

Kiedy Weber odszedł na emeryturę, His na wniosek Carla Ludwiga został w 1872 r. powołany na jego miejsce, na stanowisko kierownika Katedry Anatomicznej w Lipsku. Po objęciu stanowiska zajął się gruntowną przebudową zakładu według swoich wytycznych. Anatomia lipska została powiększona o Zakład Anatomiczno-Fotograficzny, stanowiąc przez długi czas wizytówkę nowoczesnej instytucji naukowej. W tym samym czasie, co His, na nowo powstałe stanowisko w Katedrze Anatomii Topograficznej został powołany Christian Wilhelm Braune. His i Braune w 1875 r. stworzyli podstawy metodologiczne czasopisma naukowego Zeitschrift für Anatomie und Entwicklungsgeschichte. Dwa lata

2 His jest uczonym, którego dokonania z zakresu technologii badań w obrębie mikrotomii oraz heurystycznego modelowania i wykorzystywania fotografii w analizach medycznych zostały zapomniane. Np. dagerotypii używał w swoich badaniach naukowych do poprawy prezentacji anatomicznej. Był także pionierem metody aplikacji kwasu chromowego do zwłok, którą z kolei rozwinął Gustav Born. Najważniejszym wkładem Hisa do badań medycznych był rozwój technologii związanej z mikrtomem, którą zaprezentował w 1870 r. w Archiwum Anatomii Mikroskopowej. Dzięki funkcjonalności tego urządzenia można było przygotowywać materiał biologiczny do obserwacji mikroskopowej w postaci bardzo cienkich „skrawków”.

3 Filozofowi z Królewca chodziło o „wynalezienie” sposobu myślowego dla polaczenia problematyki epistemologicznej zawartej w jego książce Krytyka czystego rozumu (Kritik der reinen Vernunft) z problematyką etyczną prezentowaną w innej jego pracy, zatytułowanej Krytyka praktycznego rozumu (Kritik der praktischen Vernunft) - a nade wszystko o podporządkowanie zasad pierwszej z nich zasadom drugiej. W ten sposób ujmowana miała być także przyroda organiczna. 
później było ono wydawane pod zmienionym tytułem Archiv für Anatomie und Physiologie. Anatomische Abtheilung. Dobre relacje obu uczonych potwierdzają pośmiertne wspomnienia Hisa o Braune, które zawierają interesujące szczegóły dotyczące rozwoju Lipskiego Wydziału Medycznego 4 .

Warto odnotować, że His po objęciu stanowiska opublikował oryginalną pracę, która przyciągnęła wielką uwagę innych uczonych. Poruszana w niej tematyka, dotyczyła rozważań bioteoretycznych w zakresie embriologii i teorii ewolucji ${ }^{5}$. W szerokim ujęciu Hisowi chodziło o rozwiązanie problematycznych kwestii ówczesnego okresu, poszukując odpowiedzi na fundamentalne pytania biologiczne, tj. jakie są mechanizmy sterujące morfogenezą zwierzęcą, czy jest możliwe ugruntowanie stałej „teorii wzrostu” etc. Najważniejsze jego prace dotyczyły głównie strukturalnej genezy układu nerwowego oraz badań w zakresie wzrostu i rozwoju nerwowych komórek embrionalnych. Znaczącym eksperymentem Hisa był ten, który został przeprowadzony na obszarze histologicznym. Do celów badawczych użył pewnej fiksacji tkanki, podzielonej wcześniej mikrotomem. Uzyskane odcinki tkankowe zrekonstruował w jedną całość, używając płaskiej metody woskowej, która została rozwinięta przez Gustava Borna. Z technicznego punktu widzenia był to ogromny postęp, który przyczynił się do rozwoju metodologii badań eksperymentalnych na obszarze morfogenezy ${ }^{6}$.

W toku ogólnych badań embriologicznych Hisa pojawia się „ostra” polemika z Ernestem Haecklem. Krytyka ze strony Haeckla była bardzo dotkliwa, ponieważ opierała się na pogardzie dla poglądów Hisa ${ }^{7}$. Ponadto uogólnienia naukowe Haeckla - jak sam wskazywał His - były dla niego mało zrozumiałe, wręcz nieczytelne, np. w swojej teorii wapiennych gąbek Haeckel krytykował teorię „sfałdowania” Hisa. Owa krytyka teorii Hisa z braku metodologicznych podstaw do jej zakwestionowania polegała na jej wyszydzeniu.

Inna znana praca Hisa o charakterze topograficzno-anatomicznym Anatomie menschlicher Embryonen powstała 1880 r. W kolejnych latach (1882 r. i 1885 r.) został opracowany jej drugi i trzeci tom. To właśnie w tej książce His zbudował i zaprezentował podstawy embriologii człowieka, które miały istotny wpływ na rozwój późniejszych badań w tym kierunku. W ramach powyższej pracy klarowała się także dalsza, „szermierka słowna" Hisa z Haecklem, która ukazywała wyraźnie zderzanie się dwóch odmiennych podejść metodologicznych w biologii rozwoju.

\section{Wilhelm His o rozwoju układu nerwowego. W poszukiwaniu swoistego „prawa wzrostu”}

W historii embriologii od dawna poszukiwano uniwersalnej „zasady” przyczynowej, która mogłaby w sposób adekwatny wyjaśniać całościowy sposób organizacji poszczegól-

4 W. His, Zur Erinnerung an Wilhelm Braune, "Archiv für Anatomie und Physiologie. Physiologische Abteilung" 1892, s. 231-257.

5 Idem, Unsere Körperform und das physiologische Problem ihrer Entstehung: Briefe an einen befreundeten Naturforscher, Leipzig 1874.

6 Idem, Beschreibung eines Mikrotoms, „Archiv für mikroskopische Anatomie” t. 6, 1870, s. $229-232$.

7 Często bywało, że uwagi krytyczne innych uczonych bywały po prostu metodologicznie słabe, a przez to łatwe do zakwestionowania i odrzucenia.

8 E. Haeckel, Die Kalkschwämme. Eine Monographie, Berlin 1872. 
nych procesów cząstkowych, przebiegających w żywych organizmach. Owe próby były nie tylko oparte na pewnych postulatach materialistycznych, lecz bywały także podbudowane założeniami metafizycznymi. Badania embriologiczne Hisa wpisują się w historyczny ciąg prac dotyczących poszukiwania fundamentalnych przyczyn odpowiedzialnych za proces formowania się ciał kręgowców. Jego uogólnienia badawcze, skupiające się na rozwoju jaja kurczęcia, stanowiły punkt wyjścia do obszernych analiz w zakresie wyjaśniania podstaw przebiegu ukierunkowanych procesów rozwojowych. W ramach tych badań uczony poszukiwał swoistego „prawa”, którego sedno mogłoby w pełni wyjaśniać przyczynowe podstawy rozwojowe każdego żywego organizmu. W tym kontekście, zaznaczał His, owe swoiste „prawo wzrostu” było już poszukiwane wcześniej przez Caspara Friedricha Wolffa, którego metodologia badawcza ujmowała przyczynowy charakter rozwoju zarodka wyłącznie w oparciu o prawa mechaniczne9. His, zmierzając do ostatecznego wyjaśnienia powyższej kwestii badawczej, postawił ważne pytanie, dotyczące dynamicznego rozwoju organicznego: według jakich stałych „praw” i „zasad” przebiegają złożone procesy organogenezy wtedy, gdy struktury embrionalne o niskim stopniu zróżnicowania przekształcają się w skomplikowane formy organów ciała żywego? Badacz zdawał sobie sprawę, że rozwiązanie tej zagadki epistemologicznej jest trudne, świadomy był także, że w niedalekiej przyszłości należy dalej skupiać się na przyczynowych badaniach, warunkujących ukierunkowany rozwój formy organicznej ${ }^{10}$.

Z dzisiejszej perspektywy pytania postawione przez Hisa w tej materii oraz próba udzielenia na nie odpowiedzi zasługują na pełny szacunek i uznanie. Pomimo ogromnego postępu wiedzy na obszarze nauk biologicznych, kwestie poszukiwania mechanizmów rozwojowych są nadal aktualne i wymagają dalszych prób eksperymentalnych i analiz teoretycznych.

Wysiłek badawczy Hisa nie ograniczał się tylko do poszukiwań ogólnej „zasady” rozpatrywanej w ramach tzw. stałego prawa wzrostu. Jego szczegółowe obserwacje dotyczyły m.in. formacji obwodowego układu nerwowego z tzw. grzebienia nerwowego oraz migracji komórek z plakody węchowej, przemieszczania się poszczególnych neuroblastów ze strefy komory zarodkowej do wierzchniej warstwy płaszcza cewki nerwowej. W 1868 r. odkrył strukturę grzebienia nerwowego. Badał jego związki w stosunku do pochodzenia rdzeniowych i czaszkowych połączeń nerwowych ${ }^{11}$. Powyższe odkrycie rodziło szereg problemów dotyczących genezy grzebienia nerwowego, sposobu migracji komórek oraz potencjalnego ich przeznaczenia. Uczony początkowo był przekonany, że formacja struktur grzebienia nerwowego bierze swój początek od pośredniego połączenia przebiegającego pomiędzy powierzchniową (skórną) ektodermą oraz płytą nerwową. Grzebień nerwowy ${ }^{12}$ - w jego ujęciu - był także organem formującym obszar zarodkowy, który zawierał różne komórki o rozmaitej potencjalności rozwojowej. Problem związany z pozycyjnymi relacjami poszczególnych komórek, rozpoczynającymi się ze struktur grzebienia nerwowego, został przez Hisa sprowadzony do teorii dotyczącej tzw. ogólnej migracji komórkowej

9 W. His, Untersuchungen über die Erste Anlage des Wirbelthierleibes. Die erste Entwickelung des Hühnchens im Ei, Leipzig 1868, s. 51.

10 Ibid.

11 Por. W. His, Untersuchungen über die erste Anlage des Wirbelthierleibes.

12 Współcześnie nazywany także czwartym listkiem zarodkowym. 
w toku morfogenezy. Badania owe były prowadzone w ramach uogólnień stricte mechanistycznych, odnoszących się do mechanistycznych pojęć i zasad rozwijanych w szkole Entwicklungsmechanik ${ }^{13}$. W ten sposób uczony poszukiwał relacji położeniowych poszczególnych komórek w toku złożonych procesów organicznych ${ }^{14}$.

W 1874 r. His ukuł czysto mechanistyczną teorię tłumaczącą swoistości układu nerwowego. Teoria ta opierała się na pewnych „tendencjach” rozwojowych przebiegających w żywym organizmie, w sposobie różnicowania się poszczególnych komórek ${ }^{15}$. Jak wykazuje Reinhard Mocek, teoria Hisa została zbudowana na podstawie prac Matthiasa Jakoba Schleidena ${ }^{16}$ oraz Theodora Schwanna ${ }^{17}$ i przyczyniła się do rozwoju innej teorii, tzw. teorii komórki, rozwijanej już w latach siedemdziesiątych XIX w.

Mimo że Robert Remak ${ }^{18}$ i Rudolph Albert von Kölliker ${ }^{19}$ byli pierwszymi uczonymi, którzy skupili swoją uwagę na morfogenezie komórek układu nerwowego, His jako pierwszy wyraźnie wskazał na ich migrację w toku neuromorfogenezy. Niewątpliwa wartość jego heurystyki badawczej została przyjęta przez różne środowiska naukowe bardzo krytycznie. Dopiero odkrycia Curta Herbsta i eksperymenty Hansa Driescha potwierdzały zapatrywania badawcze Hisa. Wskazywały one na powszechną zdolność komórek do przemieszczania się w toku różnych procesów regulacyjnych.

\section{Komórki zarodkowe, histogeneza i pochodzenie komórek nerwowych}

W 1868 r. His wprowadził do neurobiologii pojęcie neuroblastu, które odnosił do tkanki embrionalnej. W przekonaniu badacza tkanka embrionalna odpowiedzialna była za rozwój centralnego układu nerwowego w zarodku kurczęcia (epiblast), co z kolei odróżniało ją od hemocytoblastu, przyczyniającego się głównie do powstawania krwi i mezenchymy. W późniejszym czasie His kategorię neuroblastu odnosił już tylko do samych komórek, a nie do całych tkanek, które miały zapoczątkowywać rozwój neuronów. W późniejszej metodologii badawczej Hisa pojęcie to odnosiło się do neuronu we wczesnej fazie rozwojowej20.

W toku dalszych badań eksperymentalnych prowadzonych w duchu metodologii mechanistycznej embriolog udowodnit, że komórki neuroglejowe biorą swój „początek

13 Szkoła Entwicklungsmechanik reprezentowała kierunek badań wytyczony przez Hisa i Wilhelma Roux, który był jej założycielem. Początkowo do niej należał także Hans Driesch, który później, w toku rozwoju swoich poglądów witalistycznych, został wielkim przeciwnikiem wyjaśnień stricte mechanistycznych w embriologii, na korzyść wyjaśnień witalistycznych. Ze szkołą związany był także Hans Spemann (1869-1941) oraz wielu innych badaczy-eksperymentatorów z tego okresu. W szkole Entwicklungsmechanik poszukiwano generalnych mechanizmów przyczynowych rządzących rozwojem poszczególnych grup organizmów.

14 W. His, Über die Entwicklung des Riechlappens und des Riechganglions und über diejenige des verlängerten Markes, „Verhandlungen der Anatomischen Gesellschaft” t. 3, 1889, s. 63-66.

15 Por. W. His, Unsere Körperform und das physiologische Problem ihrer Entstehung. Briefe an einen befreundeten Naturforscher, Leipzig 1874.

16 Por. M.J. Schleiden, Beitrage zur Phylogenesis, „Archiv für Anatomie, Physiologie und Wissenschaftliche Medicin" t. 5, 1838, s. 137-176.

17 Por. T. Schwann, Mikroskopische Untersuchungen über die Übereinstimmung in der Struktur und dem Wachstum der Tiere und Pflanzen, Berlin 1839

18 Por. R. Remak, Untersuchungen über die Entwicklung der Wirbeltiere, Berlin 1855.

19 Por. R.A. Kölliker, Handbuch der Gewebelehre des Menschen, Leipzig 1852

20 W. His, Die Neuroblasten und deren Entstehung im embryonalen Marke, „Abhandlungen der MathematischPhysischen Classe der Königlich-Sächsischen Gesellschaft der Wissenschaften" t. 15, 1889, s. 311-372. 
rozwojowy" z neuroektodermy, a nie z mezodermy. Próbował także zademonstrować mechanizm ukazujący rozchodzenie się neuronalnych i glejowych linii rozwojowych w czasie morfogenezy ${ }^{21}$. Ostatecznie jego ujęcie badawcze, mówiące o rozwoju nabłonka nerwowego w organizmach zwierzęcych, zostało poznawczo skorygowane pod względem metodologicznym. Teoria dotycząca różnych podklas komórek zarodkowych oraz zgodności prekursorów z neuronami i komórkami glejowymi, wspierana po części przez takiego uczonego jak Santiago Ramón y Cajal, ostatecznie została uznana za sprzeczną z teorią dotyczącą pluripotencjalnych komórek progenitorowych, głoszoną przez Köllikera22.

Założenia badawcze Hisa, prezentowane na obszarze histogenezy, dotyczące korowych struktur mózgowych, zostały ostatecznie poznawczo ugruntowane. W latach sześćdziesiątych XX w. ustalono, że starsze neurony zajmują głębsze warstwy kory mózgowej, co było niezgodne ze stwierdzeniem Hisa, że owe poziomy rozwijają się sekwencyjnie począwszy od powierzchniowych warstw, aż do głębszych „pokładów” kory mózgowej.

\section{Włókna nerwowe i teoria neuronu}

Badania w zakresie neuroembriologii Hisa, Köllikera oraz innych uczonych, dotyczące fundamentalnej koncepcji neuronu, były często weryfikowane w oparciu o prace Santiago Ramona y Cajala ${ }^{23}$. Argumenty krytyczne przeciw zasadności teorii Hisa rozwijane były na płaszczyźnie embriologicznej, histologicznej, fizjologicznej i patologicznej. Dotyczyły głównie braku swoistej „ciągłości relacyjnej” pomiędzy poszczególnymi neuronami. Jednakże His, otrzymując inne wyniki eksperymentalne, których sedno polegało na barwieniu włókien nerwowych azotem srebra oraz oczernianiu ich przez ekspozycję na światło, utrzymywał, że włókna nerwowe posiadają „swobodne” zakończenia w warstwach nabłonka rogówki ${ }^{24}$. W późniejszym okresie fakt ten został potwierdzony za pomocą barwienia ich chlorkiem złota ${ }^{25}$. Prowadząc dalsze badania w tym kierunku, His usiłował także uzasadnić, że zakończenia włókien nerwowych w "centrach" mogą być „wolne”. Wyprowadzonej hipotezy badawczej nie potrafił jednak ugruntować i potwierdzić za pomocą ówczesnych technik barwienia.

Z kolei w 1879 r. His próbował uzyskać histologiczne dowody wskazujące na „przyrost" aksonów z komórek nerwowych w rdzeniu kręgowym embriona ${ }^{26}$. Przeprowadzone przez niego z niezwykłą starannością eksperymenty biologiczne zdobyły pełne uznanie Cajala $^{27}$. Ostatecznie His razem z Augustem Forelem wypracował embriologiczne pod-

21 Idem, Über die Entwicklung, s. 63-66; idem, Die Neuroblasten, s. 311-372; idem, Die Formentwickelung des menschlichen Vorderhirns vom Ende des ersten bis zum Beginn des dritten Monats, „Abhandlungen der Mathematisch-Physischen Classe der Königlich Sächsischen Gesellschaft der Wissenschaften" t. 15, 1889, s. 673736.

22 M. Jacobson, Developmental neurobiology, New York 1991, s. 43-44.

23 Por. S. Ramón y Cajal, Textura del sistema nervioso del hombre y los vertebrados, Madrid 1899-1904.

24 W. His, Beiträge zur normalen und pathologischen Histologie der Kornea, Basel 1856.

25 J. Cohnheim, Über die Endigungen der sensiblen Nerven in der Hornhaut, „Virchows Archives” t. 38, 1867, s. 343-386.

26 E.D Louis, C. Stapf, Unraveling the neuron jungle: The 1879-1886 publications by Wilhelm His on the embryological development of the human brain, „Archives of Neurology” t. 58, 2001, nr 11, s. 1932-1935.

27 W. His, Zur Geschichte des menschlichen Rückenmarkes und der Nervenwurzeln, „Abhandlungen der Mathematisch-Physischen Classe der Königlich-Sächsischen Gesellschaft der Wissenschaften" t. 13, 1887, s. 477-514. 
stawy świadczące o swoistej indywidualności zachowań neuronów. W ten sposób teoria neuronu nabrała embriologicznych podstaw metodologicznych, wskazujących, że neuroblasty powstają i przemieszczają się jako pojedyncze komórki, przy czym włókna nerwowe wyrastają z pojedynczych neuroblastów, a komórki nerwowe mają wolne zakończenia, zanim jeszcze utworzą jakiekolwiek połączenia nerwowe.

\section{W poszukiwaniu adekwatnej przyczyny rozwoju embrionalnego}

W XIX w. His był jednym z pionierów zarzucenia rozważań teleologicznych w ramach wyjaśniania osobliwości morfogenetycznych. Jego praca badawcza oparta była wyłącznie na poszukiwaniu „bezpośrednich” przyczyn embrionalnych w zakresie podstaw fizykochemicznych samego organizmu. W ramach takiego podejścia badawczego w poznaniu biologicznym w 1874 r. His opublikował książkę, która była swoistym apelem do tzw. nowej embriologii. Praca ta była zadedykowana przyjacielowi, fizjologowi Carlowi Ludwigowi, a jej celem nie było opisanie ostatecznych przyczyn rządzących procesami organogenezy, lecz ustalenie tych „najbliższych”, mechanistycznych, wpływających bezpośrednio na sterowanie i regulację procesów związanych ze wzrostem i budową określonego ciała. W tej właśnie pracy His dla lepszego zobrazowania swoich badań przyczynowych przedstawił opis rozwoju mózgu oraz sposób jego organizacji, porównując go do gumowej rurki. Celem takiego ujęcia porównawczego było ukazanie układu nerwowego kręgowców jako czegoś dynamicznego i plastycznego, podlegającego swoistym regułom fizyko-chemicznym w toku jego przyczynowej formacji. Takie właściwości - jego zdaniem - wykazywała gumowa rurka ${ }^{28}$.

Przyczynowe badania Hisa zainspirowały następne pokolenie embriologów, których pracami eksperymentalnymi kierował m.in. wielki propagator teorii mechanicznej w biologii rozwoju Wilhelma Roux ${ }^{29}$.

Warto zaznaczyć, że Jean Victor Coste dokonał rewizji ogromnej ilości materiałów badawczych z zakresu pracy naukowej Hisa. Jego zadaniem było metodologiczne prześledzenie procesu kształtowania się istoty poglądów Hisa odnośnie do złożonego rozwoju organicznego. Coste zwracał szczególną uwagę na teorię Hisa dotyczącą sposobu „połączenia" embrionów ze swoimi błonami u różnych organizmów. W tym kontekście His twierdził, że embriony człowieka są inaczej „związane” z owymi błonami niż zarodki innych kręgowców ${ }^{30}$. Przy analizie pozostałych partii materiału Hisa Coste badał także jego poglądy na temat historii rozwoju narządów ludzkich, tj. formowanie się ogona i warg, języka, szyi, nosa, mięśni, podniebienia, płatka ucha oraz fundamentalnej dla rozwoju kwestii badawczej tj. kształtowania się układu nerwowego.

Zapoczątkowana przez Hisa metodologia badawcza dotyczyła głównie uwypuklenia mechanistycznego podejścia jako stanowiska adekwatnego dla zrozumienia istoty osobliwości rozwojowych żywych organizmów, znajdujących się w stanie embrionalnego rozwoju organicznego. Jego mechanistyczne podejście do rozwoju organicznego zmusiło go

29 J. Maienschein, The origins of Entwicklungsmechanik, „Developmental Biology” t. 7, 1991, s. $43-61$.

30 Są „przymocowane” za pomocą tzw. uchwytu brzusznego. 
do odrzucenia związków ontogenetycznych poszczególnych organizmów z ich historią ewolucyjną. Swoje radykalne stanowisko poznawcze w tym zakresie utrzymywał nawet wtedy, kiedy dokładnie przeanalizował przyczynowy aspekt badań ontogenetycznych postulowanych przez Haeckla. His wyraźnie wskazywał na słabość logiczną jego postawy filogenetycznej, którą nieustannie poddawał krytyce ${ }^{31}$.

\section{O heurystyce badawczej Hisa na obszarze neuromechaniki rozwojowej}

Dzięki badaniom eksperymentalnym Hisa embriologia doświadczalna zbliżyła się do zrozumienia istoty morfogenezy na poziomie komórkowym. Chodzi m.in. o takie poruszane przez niego kwestie badawcze, jak: w jaki sposób dochodzi do strukturalnego formowania się tkanek przez poszczególne komórki, na jakiej drodze tkanki kształtują poszczególne narządy, w jaki sposób migrujące komórki docierają do miejsca finalnego przeznaczenia oraz w jaki sposób poszczególne narządy powstają w "stosunkowo odpowiednich" lokalizacjach organizmu. Jak wiadomo, podział, wzrost, różnicowanie, migracja i śmierć komórek są mechanizmami pozwalającymi na materialne kształtowanie się każdego żywego organizmu. Jednakże układ nerwowy - jak z wielkim przekonaniem twierdził His - stwarzał szczególne problemy poznawcze, ponieważ w tego typu procesach organicznych ma się do czynienia nie tylko z prekursorami neuronów, lecz także z aksonami, które muszą migrować do miejsc, w których wykonują swoiste funkcje rozwojowe, wpływając na inne połączenia obwodowe ${ }^{32}$.

Powyższe kwestie problematyczne rozwijane były przez Hisa wraz z innymi uczonymi. Przykładem może być Ross Granville Harrison, który wniósł wkład do nakreślenia swoistej historii technik badawczych na obszarze neuroembriologiï33. Udoskonalił i użył dwóch metod badawczych, stworzonych przez zwolenników szkoły Entwicklungsmechanik. W ramach powyższych badań mikrochirurgicznych prowadził także hodowlę tkanek, które później przeszczepiał. W 1903 r. przeprowadzał swoje eksperymenty biologiczne, polegające na barwieniu (bądź niebarwieniu) przeszczepów zarodkowych. W ten sposób ustalał, w jaki sposób komórki migrują w wyznaczonych kierunkach oraz na jakiej drodze stają się organami czuciowej linii bocznej organizmu. Harrison jest także znany z badań nad wzrostem i migracją aksonów. His i Cajal również prowadzili badania tego typu. Popierali oni teorię głoszącą, że aksony biorą swój „początek” z ciała komórki34. Cajal na określenie tego osobliwego zjawiska ukuł termin „stożek wzrostu”. Bezpośrednim potwierdzeniem hipotezy Hisa i Cajala były obserwacje mikroskopowe związane ze wzrostem aksonów. Harrison jednak był pierwszym uczonym ${ }^{35}$, który zweryfikował proces formowania się

31 Por. R.J. Richards, The tragic sense of life: Ernst Haeckel and the struggle of evolutionary thought, Chicago 2008; N. Hopwood, Haeckel's embryos, Image, evolution and fraud, Chicago 2015.

32 Ibid.

33 J.M. Oppenheimer, Ross Harrison's contributions to experimental embryology, „Bulletin of the History of Medicine" t. 40, 1966, nr 6, s. 525-543.

34 Ciało komórki, zwane także soma, jest sferyczną częścią neuronu i zawiera jądro. Ciało komórki łączy się z dendrytami, które przekazują informacje do neuronu i aksonu, a dalej są przekazywane do innych neuronów. Kiedy informacja jest odbierana od innego neuronu, dendryt przekazuje sygnał do ciała komórki.

35 Harrison był także pierwszym uczonym, który systematycznie badał przyczynowe relacje zachodzące pomiędzy ruchami poszczególnych komórek. W ten sposób uzgodnił, że pierwotne włókna nerwowe „wyprzedzają” inne 
włókna nerwowego oraz dopatrzył się osobliwych ruchów związanych ze „stożkiem wzrostu". Swoje obserwacje potwierdził w toku prowadzonych prac w zakresie eksperymentów mikrochirurgicznych ${ }^{36}$. Usuwając grzbietową część cewy nerwowej embriona żaby, uzyskał w jej organizmie przyrost naturalnych włókien nerwowych. Badania te wyraźnie potwierdzały wcześniejszą hipotezę ukutą przez Hisa i Cajala. W tym kontekście eksperymentalnym His zauważył, że przednie włókna korzeniowe, odpowiedzialne za funkcje motoryczne, wyrastają z rdzenia kręgowego, podczas gdy tylne, czuciowe, biorą swój początek poza nim i tylko wrastają w niego.

His obserwował także liczne postaci mitotyczne komórek wewnątrz nabłonka nerwowego embriona pisklęcia. Wysunął hipotezę, że szybkie ich namnażanie się może odgrywać wiodącą rolę w procesie „fałdowania” się płyty nerwowej oraz podczas formacji cewki nerwowej37. Biologiczne zjawiska rozpoznane przez niego były weryfikowane w późniejszym czasie i należały do podstawowych dla rozwoju współczesnych badań przebiegających $w$ tym samym kierunku ${ }^{38}$. Miały one fundamentalne znaczenie dla rozwoju tzw. teorii nerwów, ostateczne ugruntowanej przez Camillo Golgiego i Santiago Ramona y Cajala.

Powyższe kwestie badawcze były przedmiotem wielu sporów i kontrowersji. Ostatecznie w dziedzinie biologii rozwoju została przyjęta zasada mówiąca o wzajemnym współdziałaniu różnych typów komórek w toku procesów morfogenetycznych. Badania w zakresie molekularnego determinizmu migracji komórek wykazały, że mechaniczne "kierowanie" aksonem jest możliwe dzięki pewnym gradientom adhezji albo swoistym różnicom w specyficzności „przylegania”, obejmującym cząsteczki adhezyjne. Wysiłki badawcze Johannesa Holtfretera sprowokowały umysły uczonych do opracowywania modeli termodynamicznych, odnoszących się do złożonych relacji zachodzących pomiędzy poszczególnymi komórkami w toku rozwoju organizmów ${ }^{39}$.

aksony i „służą” jako swoiste przewodniki rozwojowe w toku organizacji układu nerwowego. Ustalił także, że komórki posiadają swoistą tendencję rozwojową „przyczepiania się" do stałych powierzchni, a strukturalne różnice pomiędzy rozmaitymi powierzchniami embrionalnymi mogą być jednym z decydujących czynników „migracji” aksonów oraz ich potencjalnego wyboru.Takie podejście badawcze znacznie uprościło problem orientacji "stożków wzrostu”. Paul Weiss, akceptując te wyniki badawcze, dodatkowo rozszerzył swoją tezę o twierdzenie, że w toku złożonych procesów organogenezy, poszczególne komórki znajdują się między sobą w ścisłej relacji zależnościowej, wzajemnie przekazując sobie różne zadania. Por. R.G. Harrison, The reaction of embryonic cells to solid structure, "Journal of Experimental Zoology" t. 17, 1914, nr 4, s. 521-544.

36 R.G. Harrison, Observations on the living developing nerve fiber, "Anatomical Record" t. 1, 1907, nr 1, s. 116 118; R.G. Harrison, Neuroblast versus sheath cell in the development of peripheral nerves, "The Journal of Comparative Neurology" t. 37,1924, nr 1, s. 123-206.

37 W. His, Unsere Körperform.

38 Por. R. Jelinek, Z. Friebova, Influence of mitotic activity on neurulation movements, "Nature” t. 209, 1966, nr 5025, s. 822-823.

39 Oprócz zjawisk pozycyjnych i relacyjnych zachodzących pomiędzy poszczególnymi komórkami embriologia doświadczalna podkreśla ważną rolę substancji ulegających dyfuzji np. czynników wzrostu. Odkrycie pierwszego z nich, nerve growth factor (NGF), który bierze głównie udział w regulacji wzrostu, utrzymania, rozmnażania i przetrwania niektórych docelowych neuronów, było kamieniem milowym w rozwoju neuroembriologii. Zidentyfikowano także wiele procesów biologicznych z udziałem NGF, z których dwa to przeżycie komórek beta trzustki oraz regulacja układu odpornościowego. Wspomniany czynnik wzrostu po raz pierwszy został wyizolowany i opisany w 1956 r. przez laureatów Nagrody Nobla Ritę Levi-Montalcini i Stanleya Cohena. 


\section{Zakończenie}

His odegrał dużą rolę w kształtowaniu się metodologicznych podstaw szkoły Entwicklungsmechanik. W późniejszym okresie wykazano, że teoria mechanistyczna rozwijana w jej ramach okazała się niewystarczająca w poznaniu biologicznym, wpisywała się ona jednak w ciąg badań historycznych, na podstawie których wyłoniło się podejście neowitalistyczne. Mechanistyczne pojmowanie embrionalnych procesów rozwojowych było często krytykowane przez zwolenników podejścia teleologicznego i dawało metodologiczne podstawy do reaktywacji podejścia witalistycznego. Z kolei witalizm dominował w biologii przez długi czas, a jego upadek nastąpił w latach trzydziestych XX w. ${ }^{40}$

His jako jeden z pierwszych uczonych podejmował rozważania nad naturą przyczynowych czynników epigenetycznych oraz wiązał swoje teoretyczne rozważania z pracami eksperymentalnymi w obszarze morfogenezy. W tym sensie jego prace badawcze ujawniały złożoność embriologicznych procesów rozwojowych na poziomie komórkowym. Jego przyczynowe badania eksperymentalne w ramach poszczególnych zależności komórkowych oraz ich mechanistyczna interpretacja wytyczyły nowe granice badań w rozwoju neuroembriologii. Spowodowały one, że coraz większa grupa uczonych kierowała uwagę na początkowe stadia rozwojowe żywych organizmów. Dalsze eksperymenty prowadzone w tym duchu dotyczyły mechanicznego uszkadzania blastomerów albo ich „oddzielania" lub „łączenia” za pomocą różnych technik eksperymentalnych. Pamiętano przy tym o zachowaniu precyzyjnego opisu badawczego, dotyczącego poszczególnych podziałów komórkowych w odniesieniu do całościowego rozwoju badanego organizmu zwierzęcego. Wystarczy tutaj wskazać na Wilhelma Roux oraz Hansa Driescha, których wysiłki zmierzały do ostatecznego wyjaśnienia podstawowych relacji przyczynowych podczas rozwoju żywych organizmów i były prowadzone w oparciu o rozmaite założenia i perspektywy badawcze.

W wieloaspektowej pracy badawczej Hisa na szczególne wyróżnienie zasługuje-oprócz jego skrupulatnych badań eksperymentalno-teoretycznych w zakresie neuroembriologii - próba sprecyzowania ogólnej „zasady wzrostu”, odnoszącej się do przyczynowego rozwoju organizmów. Dzisiaj nadal poszukuje się takiego osobliwego „prawa”, którego sedno mogłoby w pełni wyjaśnić przebieg procesów regulacyjnych w toku dynamicznego rozwoju organicznego. Jego zmysł techniczny, który doprowadził do ulepszenia technik eksperymentalnych, również zasługuje na uznanie.

Dlaczego jednak tak duży wkład badawczy Hisa do nauki, szczególnie do medycyny i biologii rozwoju, został zapomniany? Wydaje się, że taki stan rzeczy został spowodowany szybkim rozwojem nauk przyrodniczych, które przysłoniły jego osiągnięcia naukowe w zakresie szeroko pojętej biologii. Inną przyczyną może być brak adekwatności w wyjaśnianiu osobliwości życia organicznego przez koncepcję neomechanistyczną z przełomu XIX i XX w. ${ }^{41}$

40 Nie oceniam tutaj szczegółowo ani ogólnej teorii neomechanistycznej ani ogólnej teorii neowitalistycznej. Takie kompleksowe ujęcie, uwzględniające metodologiczną „przydatność” poszczególnych teorii w poznaniu biologicznym, wymaga osobnego, kompleksowego opracowania. Można tutaj tylko wskazać, że z metodologii biologii prezentowanej przez poszczególnych badaczy, dotyczącej wieloaspektowych osobliwości organicznych w toku rozwoju organizmu, daje się wydobyć pewne wartościowe i przydatne ujęcia, zarówno na poziomie opisowym jak i wyjaśniającym, które dzisiaj dalej należy rozwijać i uzupełniać.

41 Są to tylko hipotezy robocze, a cały problem wymaga osobnego, gruntownego opracowania. 
Pomimo różnych błędów w strategii badawczej Hisa jego życiowy dorobek naukowy zasługuje na wielki szacunek i uznanie ${ }^{42}$. Szkoda tylko, że nadal pozostaje na marginesie najnowszej historii medycyny, biologii rozwoju oraz szeroko pojętej filozofii przyrody.

\section{Bibliografia}

\section{Źródła}

Cohnheim J., Über die Endigungen der sensiblen Nerven in der Hornhaut, „Virchows Archiv" t. 38, 1867.

Haeckel E., Biologie der Kalkschwämme, Berlin 1872.

Haeckel E., Ziele und Wege der heutigen Entwicklungsgeschichte, Jena 1875.

Harrison R.G., Neuroblast versus sheath cell in the development of peripheral nerves, „The Journal of Comparative Neurology" t. 37, 1924, nr 1.

Harrison R.G., Observations on the living developing nerve fiber, "Anatomical Record" t. 1, 1907, nr 1.

Harrison R.G., The reaction of embryonic cells to solid structure, „Journal of Experimental Zoology" t. 17, 1914, nr 4.

His W., Anatomie menschlicher Embryonen, Leipzig 1880-1885.

His W., Beiträge zur normalen und pathologischen Histologie der Kornea, Basel 1856.

His W., Beschreibung eines Mikrotoms, „Archiv für mikroskopische Anatomie” t. 6, 1870. His W., Die Entwicklung der ersten Nervenbahnen beim menschlichen Embryo. Übersichtliche Darstellung, „Archiv für Anatomie und Physiologie Anatomische Abtheilung” t. 92, 1887.

His W., Die Formentwickelung des menschlichen Vorderhirns vom Ende des ersten bis zum Beginn des dritten Monats, „Abhandlungen der Mathematisch-Physischen Classe der Königlich Sächsischen Gesellschaft der Wissenschaften" t. 15, 1889.

His W., Die Neuroblasten und deren Entstehung im embryonalen Marke, "Abhandlungen der Mathematisch-Physischen Classe der Königlich Sächsischen Gesellschaft der Wissenschaften" t. 15, 1889.

His W., Über die Entwicklung des Riechlappens und des Riechganglions und über diejenige des verlängerten Markes, „Verhandlungen der Anatomischen Gesellschaft” t. 3, 1889.

His W., Ueber die Prinzipien der tierischen Morphologie. Brief an Herrn John Murray, "Naturwissenschaftliche Rundschau" t. 4, 1888, nr 38.

His W., Unsere Körperform und das physiologische Problem ihrer Entstehung. Briefe an einen befreundeten Naturforscher, Leipzig 1874.

His W., Untersuchungen über die Erste Anlage des Wirbelthierleibes. Die erste Entwikkelung des Hühnchens im Ei, Leipzig 1868.

W. His, Zur Erinnerung an Wilhelm Braune, „Archiv für Anatomie und Physiologie. Physiologische Abteilung" 1892.

42 Anatom Wilhelm Waldeyer jako jeden z nielicznych uczonych doceniał osiągnięcia badawcze Hisa, które współcześnie są praktycznie zapomniane: W. Waldeyer, Wilhelm His, Sein Leben und Wirken, „Deutsche Medizin” t. 39, 1904, nr 41, s. 1-26. 
His W., Zur Geschichte des menschlichen Rückenmarkes und der Nervenwurzeln, „Abhandlungen der Mathematisch-Physischen Classe der Königlich Sächsischen Gesellschaft der Wissenschaften" t. 13, 1887.

Kölliker R.A., Handbuch der Gewebelehre des Menschen, Leipzig 1852.

Ramón y Cajal S., Textura del sistema nervioso del hombre y los vertebrados, Madrid 1899-1904.

Remak R., Untersuchungen über die Entwicklung der Wirbeltiere, Berlin 1855.

Schleiden M.J., Beitrage zur Phylogenesis, „Archiv für Anatomie, Physiologie und Wissenschaftliche Medicin" t. 5, 1838.

Schwann T., Mikroskopische Untersuchungen über die Übereinstimmung in der Struktur und dem Wachstum der Tiere und Pflanzen, Berlin 1839.

\section{Literatura przedmiotu}

Bartel H., Embriologia, Warszawa 2002.

Dupont J.C., Wilhelm His and mechanistic approaches to development at the time of Entwicklungsmechanik, Berlin 2017.

Hopwood N., Haeckel's embryos. Image, evolution and fraud, Chicago 2015.

Jacobson M., Developmental neurobiology, New York 1991.

Jelinek R, Friebova Z., Influence of mitotic activity on neurulation movements, "Nature" t. 209, 1966, nr 5025.

Louis E.D, Stapf C., Unraveling the neuron jungle: The 1879-1886 publications by Wilhelm His on the embryological development of the human brain, "Archives of Neurology" t. 58, 2001, nr 11.

Maienschein J., The origins of Entwicklungsmechanik, „Developmental Biology”, 1991.

Oppenheimer J.M., Ross Harrison's contributions to experimental embryology , "Bulletin of the History of Medicine" t. 40, 1966, nr 6.

Richards R.J., The tragic sense of life: Ernst Haeckel and the struggle of evolutionary thought, Chicago 2008.

Dariusz Adam Szkutnik jest absolwentem filozofii Uniwersytetu Jagiellońskiego (magisterium) i Uniwersytetu Warszawskiego (doktorat). Swoje badania prowadzi wokół metodologii biologii, podejmując głównie problematykę filozoficznych aspektów integracji i regeneracji organicznej w toku morfogenezy.

e-mail: theskutnik@gmail.com.

Data zgłoszenia artykułu: 6 lutego 2019

Data przyjęcia do druku: 10 października 2019 